\title{
Article \\ The Dark Side of Managing for the Long Run: Examining When Family Firms Create Value
}

\author{
Kyuho Jin ${ }^{1, *} \mathbb{C}$, Joowon Lee ${ }^{2}$ and Sung Min Hong ${ }^{3}$ \\ 1 Division of Liberal Arts and Sciences, GIST College, Gwangju Institute of Science and Technology, \\ Gwangju 61005, Korea \\ 2 Department of Management, School of Business, George Washington University, 2201 G St NW, \\ Washington, DC 20052, USA; joowonlee9732@gwmail.gwu.edu \\ 3 Institute of Management Research, Business School, Seoul National University, 1 Gwanak-ro, Gwanak-gu, \\ Seoul 08826, Korea; koi4@snu.ac.kr \\ * Correspondence: kyuhojin@gist.ac.kr
}

Citation: Jin, K.; Lee, J.; Hong, S.M The Dark Side of Managing for the Long Run: Examining When Family Firms Create Value. Sustainability 2021, 13, 3776. https://doi.org/ $10.3390 /$ su13073776

Academic Editor: Sajid Anwar

Received: 28 February 2021

Accepted: 24 March 2021

Published: 29 March 2021

Publisher's Note: MDPI stays neutral with regard to jurisdictional claims in published maps and institutional affiliations.

Copyright: () 2021 by the authors. Licensee MDPI, Basel, Switzerland. This article is an open access article distributed under the terms and conditions of the Creative Commons Attribution (CC BY) license (https:// creativecommons.org/licenses/by/ $4.0 /)$

\begin{abstract}
Family firms take a substantial fraction of economic activities and significantly influence a nation's economic sustainability. Despite the considerable amount of research efforts to determine their performance implications, there is still a lack of consensus. This study aims to address this dissensus in two ways. Theory-wise, we introduce two interdependent contingencies that interactively determine the relative strength of positive and negative effects of family involvement: inside chief executive officers (CEOs) and business fluctuations. Method-wise, we employ an advanced econometric technique, the system generalized method of moments (GMM) estimator, to control for endogeneity. Using panel data of Korean family firms listed on the Korea Composite Stock Price Index (KOSPI) stock market during the periods between 2013 and 2016, we find (1) that family firms underperform non-family firms, (2) that the negative effect of family involvement decreases under the management of inside CEOs, and (3) that this positive moderation effect of inside CEOs decreases in the face of business fluctuations. This study furthers our understanding of how the family influences firm performance and, eventually, economic sustainability.
\end{abstract}

Keywords: family firms; inside CEOs; outside CEOs; business fluctuations; economic sustainability

\section{Introduction}

Family-owned businesses or family firms are ubiquitous around the world. They account for approximately two-thirds of private businesses [1-3] and take a substantial fraction of wealth creation and job generation [4]. Given that a country's economic sustainability is determined, at least in part, by the competitiveness of market agents, primarily firms [5,6], family firms and their competitiveness is germane to the analysis of economic sustainability. Unfortunately, however, our understanding of whether family involvement promotes firm competitiveness and, ultimately, economic sustainability is hindered by contradictory findings [7-10]. Some studies report a positive effect of family involvement on firm performance [11-14], whereas other studies exhibit a negative effect $[15,16]$. Another thread of studies finds no significant relationship between the two [17]. To compound this contradiction, most of these studies have been methodologically neglectful of controlling for the endogeneity widely believed to plague the relationship between ownership and performance [18-20].

This study aims to alleviate this inconclusiveness. To begin, we underscore the distinguishing characteristics of the family as a corporate owner. Indeed, the family brings various organizing benefits to its firm such as social embeddedness, solidarity, and identification with the firm, organizational trust, and strong commitment, all of which serve as social capital, enhancing the organizational efficiency [21-24]. At the same time, however, the family represents an idiosyncratic value-destroying tendency: managing for 
the future to pass its firms down onto its descendants even at the expense of the current economic profit $[25,26]$. This disparate motive often derails the family out of rational, economic ways of thinking and decision making, steering the firm in the strategically wrong direction. Symptomatic examples include excessive risk avoidance, passing up promising opportunities for fear of control loss, amateurism, and nepotism, which all have some bearing on socio-economic wealth preservation to the detriment of firms' economic well-being (for a review, see [27]). Put differently, the family may spur its firm in the suboptimal direction, wasting organizational efforts and resources. So, we herein conjecture that family firms underperform non-family firms.

Then, we draw attention to the possibility that the benefit and cost that the family delivers are contingent upon other situational factors. To the extent that this possibility is true, omitting such situational factors or contingencies from consideration can mask the real effect of family involvement on firm performance. In this vein, we claim that the empirical disagreement derives from contingencies that have evaded scrutiny in the prior literature. A growing body of literature has made progress along this line by casting attention to such contingencies as family identity [28], geographic location [20,29], firm size [10], and ownership type $[15,30]$. In accordance with these studies, we consider two additional contingencies-inside (or internally promoted) chief executive officers (CEOs) and business fluctuations - that possibly moderate the relationship between family involvement and firm performance. More importantly, we examine a second-order contingency that could regulate the interdependent nature of these two contingencies by introducing a three-way interaction. By so doing, we attempt to add analytic precision to the logic and mitigate theoretical uncertainties that have clouded the relationship. Specifically, we put forth that the benefit of family involvement strengthens when the CEO is internally promoted rather than hired from the outside. Inside CEOs are well-aware of all the information and knowledge of family business operations regarding history, culture, organizational routines, managerial practices, value systems, and social capital, all of which could be leveraged for competition. So, the negative net effect of family involvement we surmise above will get tilted toward the positive side. Plus, we envisage that this positive moderating effect of inside CEOs on the relationship between family involvement and performance will be diluted if family firms experience business fluctuations. We reason that the need for outside CEOs armed with diverse knowledge and information and external networks for stabilizing businesses gets pronounced in the presence of such business uncertainties.

We test these hypotheses using panel data of Korean firms listed on KOSPI (The Korea Composite Stock Price Index), an equivalent to the S\&P 500 in the US, during the period between 2013 and 2016. This sampling strategy allows us to analyze most of Korea's prominent companies, such as Samsung Electronics and Hyundai Motors. Korea offers an ideal setting for testing our theory for several reasons. First, family ownership is one of the dominant corporate ownership types in Korea [2]. For example, family firms comprise about $60 \%$ of our sample. Second, Korea's relatively weak corporate governance system allows the negative aspect of family involvement to be effective while its Confucious culture and tradition that have given birth to strong social capital such as cohesion, solidarity, loyalty, and trust typically observed in family firms boost the positive effects of familiness [31,32]. So, the two theoretical mechanisms we put forth are likely at work simultaneously. Method wise, this study employs an advanced econometric technique, the Blundell and Bond's [33] system GMM estimator, to address the endogeneity concern. By using covariates' lagged values as instruments and offering various test statistics to evaluate the instruments' validity, this estimator enables us to get consistent estimates of family involvement that are safe from various types of endogeneity. The empirical results lend support for all the hypotheses.

Our study adds to our knowledge of economic sustainability in general and family firms in particular on multiple fronts. First and foremost, we shed light on family firms as a crucial agent for determining the sustainability of a national economy, and carefully examine their performance implications. Even if family firms serve as one of the most dominant 
players in the economy, they have often been overlooked in the economic sustainability consideration. By bringing family firms to the fore, we redress this omission. Second, we find that family involvement negatively influences firm performance once the endogeneity is controlled for. This result points to the possibility that empirical estimates from the prior studies failing to control for endogeneity might have been biased. The endogeneity control, by implication, is not an option but an imperative for any analysis delving into the relationship between ownership and performance. Finally, this study offers an advanced and nuanced understanding of the long-debated question of the family's role in the economy by demarcating the boundary within which family firms possibly contribute to economic performance and, in aggregation, the sustainability of a national economy. Our results suggest that family firms create more value if the CEO is internally promoted. Moreover, this value is maximized when business prospects are relatively stable.

\section{Theory and Hypotheses}

Family firms are defined as the firms over which the family exercises decisive managerial control. Family control arises from stock ownership, managerial or board position, historically derived status, or a combination of the three. There is no dearth of evidence that family firms wield considerable influence on economic activities [2,12,27,34]. Therefore, the family business literature has investigated the impact of the family on a variety of strategic choices and outcomes such as succession, professionalization, risk-taking, diversification, human resource practices, and eventually financial performance [27]. At the crux of the investigation lies the conception of "familiness" [35]. Familiness pertains to the behavioral characteristics of the family that differentiate it from the other sorts of corporate owners by putting an added emphasis on non-economic factors orthogonal to the economic principle [36].

However, the reliance on non-economic rationales does not necessarily mean that the family is invariably irrational. Rather, this merely indicates that the family may pursue a different objective than economic optimization, depending upon the situation. For example, the family is considered to behave in a rational and sophisticated fashion when it comes to preserving family assets. Family assets are not something to be consumed now by family members of the current generation but a legacy to be successively passed down to their descendants, hopefully for good. Hence, what makes family behaviors idiosyncratic and seemingly irrational is that the family prioritizes the preservation and perpetuation of family assets and regards economic rationales as subordinate to the non-economic motive. As per this idea, Gomez-Mejia and colleagues [27,36,37] introduced a novel conception of "socioemotional wealth" that highlights the emotional aspect of the family's decision making. Not surprisingly, behavioral distinctiveness of this kind renders the family's effect on economic profit equivocal.

Such a peculiarity of the family bears both positive and negative consequences, be they purported or inadvertently derived. In this respect, the family effects can be best described as "a double-edged sword." Given the countervailing effects simultaneously at work, it is not surprising that the literature has failed to reach an empirical agreement. This indicates that for anybody who aims to examine the family's net effect, it would be more profitable to probe into contingencies that make either effect greater than the other. Before jumping into these contingencies, we detail the positive and negative sides of the family involvement in what follows.

The family is known to promote the accumulation of various types of resources and capabilities by virtue of kinship-based social embeddedness, solidarity, and identification with the firm. Based on a thick skein of kinship-based interpersonal relations, the family nurtures organizational trust $[38,39]$ and induces organizational members' strong commitment [40], leading to business success and longevity. Moreover, so derived trust as an organizing principle for family firms [41] functions as a precursor to stewardship [42], altruism [43], and, viewed broadly, social capital [44,45]. In particular, social capital—the goodwill and resources accumulated via reciprocal, trusting relationships—as a valuable, 
rare, costly to imitate resource provides family firms with a sustainable competitive advantage [46], given that social capital curbs opportunistic behaviors by offering social glue and thereby facilitates cooperation and collaboration among employees [47,48]. In a similar vein, organizational trust rooted in familial relations fosters a sense of identification with the firm [49] and provides the firm with a steady supply of trustworthy human resources [50].

The long-term orientation (this is defined as the tendency to prioritize the long-range implications and impact of decisions and actions that come to fruition after an extended time period [51]) is considered a common characteristic observed in most family businesses that helps improve performance [12,26,43]. Research evidence reveals that family firms make investments from a longer-term perspective than non-family firms do, the main reason being that the family desires to pass the firm onto its subsequent generations [43]. Hence, family firms are less likely to fall victim to managerial myopia and short-termism-derived malaises such as passing up good investment opportunities for the current earnings. In support of this view, a growing body of research finds that a longterm orientation enhances firm performance operationalized as traditional profitability measures [12,52,53], efficiency [54] and sale growth [55-57]. Indeed, family firms with a long-term orientation are better positioned than non-family firms to protect long-lived assets such as reputation and legacy [58-60], another source of sustainable competitive advantage [61,62]. Furthermore, in long-term-oriented firms, managers act more like stewards than agents, reducing agency costs pervasive in organizations with widely dispersed ownership structures $[63,64]$.

At the same time, the family also holds negative consequences [24,65], sowing the seeds of diverse pathological symptoms. First, family firms are laden with the tendency of nepotism, the preferential treatment of family members in an employment context by giving them positions regardless of merit or abilities [66,67]. Research evidence reveals that family members are treated favorably vis-à-vis non-family members in the context of hiring, performance appraisal, and promotion or compensation decisions [1,67]. Worse yet, this tendency is likely to cultivate a non-professional, amateurish culture, interfering with professionalization and specialization [68]. Furthermore, nepotism triggers the expropriation of wealth by offering excessive compensation or special dividends exclusively to family members [69]. In all, to the extent that family members whose capabilities are under par or not qualified assume a crucial role in family businesses, nepotism creates a drain on competitiveness and the viability of the family businesses $[9,70]$.

Second, family firms are generally conservative [71] and resistant to change [72]. As discussed, family firms are not something to use up for this generation but a legacy to be preserved for and passed down to their descendants. The resulting extended management horizon may shift the behavioral orientation blindly towards the longer term, making the family shy away from urgent risk-taking required for competition and survival $[70,71]$. Moreover, behavioral regularities observed in family firms tend to be self-perpetuating. As a natural outgrowth of strong kinship-based relations and interactions therein, familiallyderived organizing methods such as operating procedures, routines, rituals, and culture are all imbued with family values and bonds, and thereby progressively become a family legacy to preserve for the future. It follows that family firms are more likely to be reluctant to adapt and change than non-family firms [36,73]. However, organizational adaptations and changes are prerequisites for business development and growth, especially under environmental volatility [74]. Without timely adaptations and changes, organizational effectiveness could be severely damaged.

Given that the two countervailing effects are in operation at once, it is difficult to predict that one effect outweighs the other. Nonetheless, we hold that the negative effects are more significant by drawing on the analogy of a vector widely used in mathematics and physics. A vector comprises two elements: direction and magnitude. From the vectorial standpoint, to reach the destination quickly, one has to move fast (i.e., efficiently) in the right direction (i.e., effectively). Family-based advantages have more to do with 
"magnitude" in that they are primarily based on the social capital intended to enhance production efficiency, whereas their liabilities have more to do with strategic "direction" or effectiveness because the pathological symptoms sub-optimize the strategic choices. Hence, similar to the orthogonal projection of a vector in another vector space onto the focal vector space, which is less than one [75], the resulting outcome will fall short of the optimum although the production efficiency (i.e., social capital) hits the maximum if the efforts are in the sub-optimal direction. Thus, we hypothesize:

\section{Hypothesis 1. Family firms will underperform non-family firms.}

\section{Moderating Effects of Inside CEOs and Business Fluctuations}

Most family firms are bound to go through professionalization along various dimensions such as organizing methods, structure, and management techniques with the passage of time. A critical driver of such professionalization is the incorporation of outside CEOs who, as professional managers, are equipped with state-of-the-art knowledge about the business trend and managerial know-how. Not a few studies have elaborated on several benefits that outside CEOs can bring to the firm. First, outside CEOs' interpersonal networks or social capital can offer conduits through which to secure access to external information and resources [76,77]. They do so by introducing into the firm a channel for non-routine information flows via their advice networks of executives at other firms [78], which helps figure out high-quality solutions to the strategic challenges [79] and improve the decision-making quality at the top management team (TMT) level [80]. Similarly, outside CEOs are found to help firms promote their adaptive capacity and realize positive financial outcomes [81]. To conclude, outside CEOs expand the knowledge- and information-base, on the basis of which firms can leverage organizational processes for competitive advantage [80,82].

Not surprisingly, however, incorporating outside CEOs and giving them authority to control the entire firm may cause non-trivial organizational disruption since any leadership changes are likely to accompany revamps and reshuffles in the managerial methods and organizing pattern [83]. The operation of family firms is tightly coupled with and guided by their managerial system of which logic is qualitatively distinct from that of non-family firms in terms of the source of authority, the leadership style, the degree of formalization, the compensation scheme, the need for relying on contracts, and the like [27]. Outside CEOs are generally unfamiliar with such idiosyncrasies of family firms due to their ignorance of unique historical trajectories and the managerial legacy requisite to understanding the social construction process of the family-established management system. They are devoid of social capital through which to build affinity with and integrate into top management teams, hampering decision-making processes and thereby deflating economic performance [84]. Likewise, outside CEOs do not have an in-depth understanding of the firm-specific competencies [85] and the firm's organizational environment [86] to steer in the right direction.

In contrast, inside CEOs do not fall prey to these sorts of symptoms. They have already had hands-on experiences and opportunities of gathering and understanding all the historical and social knowledge of the family firm's developmental path, firm-specific resources and capabilities, and surrounding environments. Further, during their long tenure at the firm, they should have developed an extensive interpersonal network or social capital in the firm that is critical to effectively managing an organization. Employing this superior knowledge and social capital, inside CEOs are in a better position than outside CEOs to take advantage of the bright side of familiness, that is, the advantage of family firms will augment further under the management of inside CEOs, compensating for the negative effect of family management. Thus, we hypothesize:

Hypothesis 2. The relationship between family firms and performance will be positively moderated by inside CEOs, such that when family firms are managed by inside CEOs, the negative effect of family firms gets weaker. 
As with other types of firms, family firms experience the ups and downs of their businesses. Such business fluctuations can come about for various reasons, including navigating through the inchoate stage of development and bearing excessive risk. However, our sample consists of large and established family firms listed on the KOSPI market, which are already in a mature state. Moreover, family firms, in general, are reluctant to bear excessive risks, as explained. Two more probable reasons for business fluctuations in our empirical context may be (1) less professionalized (or amateurish) family management and (2) lack of diversity in cognitive bases under conditions of environmental volatility.

Even if family firms are compelled to undergo professionalization over time, the extent to which management is professionalized in a substantive sense could vary according to myriad firm-specific factors. Amateurs' decision-making is likely to suffer from the lack of a systematic framework on which to base important strategic decision-making. Absent systematic guidance, decision-makers tend to refer more to epi-phenomenal situational factors and therefore exhibit greater variance. Inside CEOs cannot be a solution under this situation since they inherit all the belief systems and management techniques from inside. Contrarily, outside CEOs as professional managers are highly experienced, externally trained, and therefore armed with the systematic framework by which to manage and stabilize businesses.

On the other hand, family firms are a kind of small, close-knit, cohesive society in which cognitive systems (mentality, values, beliefs, and assumptions), as well as emotional elements (e.g., attachment, identification, trust, and loyalty), are strongly shared based on kinship-based relations. In such a context, homogeneity in cognitive structure and the frame of reference not only materializes but progressively deepens over time. So induced homogeneity often engenders syndromes, seriously polluting decision-making processes such as groupthink and tunnel vision that get particularly problematic in the presence of business fluctuations [87]. When their businesses get unstable, firms should search for and explore solutions along various dimensions [88]. This is precisely the time when firms are heavily in need of the diversity of cognitive bases. However, inside CEOs who also share the cognitive structure with other family firm members would merely add to this homogeneity. By contrast, outside CEOs can resolve this pathological uniformity in cognitive structure by bringing to family firms diverse knowledge and information, cognitive bases and filters, experiences, world views, value systems, risk preferences, and the like, that can serve as antidotes to the environment-derived business fluctuations [89].

Taken together, it stands to reason that the positive moderating effect of inside CEOs on performance will attenuate under business fluctuations. Thus, we hypothesize:

Hypothesis 3. The moderating effect of inside CEOs will be moderated by business fluctuations, such that as business fluctuations increase, the positive moderating effect of inside CEOs decreases.

\section{Data and Methods}

\subsection{Sample}

We test our hypotheses in the context of Korean firms listed on KOSPI (Korea Composite Stock Price Index) during the period between 2013 and 2016 (since this sample period may be too short to represent the entire period, we conducted t-tests by using two indicators of the Korean economy from 2000 and 2020: (1) real GDP growth rates (to assess economic munificence) and (2) annualized standard deviations of the KOSPI daily stock market index (to assess economic uncertainty). According to the results, there was no significant difference between our sample period and the other period in real GDP growth rates. However, our sample period is statistically different from the other period in terms of annualized standard deviations at $p<0.05$; our sample period is less uncertain. Given that a stable environmental condition generally favors family firms, our chosen sample period offers a conservative test of our hypothesis that predicts the negative effect of family involvement). Korea provides a proper setting for our analysis for three reasons. First, family ownership in Korea is one of the most dominant corporate owners types, 
wielding considerable power over their economies [2]. So, research on family firms gains practical significance. Second, as Korea's corporate governance system is relatively less advanced $[90,91]$, the negative aspect of family ownership has a greater opportunity to manifest itself. Finally, at the same time, Korea has long been influenced by the culture and tradition marked by Confucianism, in which the family serves as a basic social building block. Social capital such as cohesion, solidarity, trust, loyalty, and hierarchical order are typically imprinted on the value of family firms in Korea and arguably boost the positive aspect of family involvement [31,32]. Accordingly, the theoretical processes we herein put forth and examine are likely at work simultaneously in Korean family firms.

Our initial sample came from the firms listed on KOSPI (KOSPI is comparable to S\&P 500 in the U.S.) during the period between 2013 and 2016. These firms are thought to represent Korean firms well. We gathered financial information from KISVALUE (which is comparable to COMPUSTAT in the United States) and non-financial information from DART (Data Analysis, Retrieval, and Transfer system) offered by the Korea Financial Supervisory Service (http:/ / dart.fss.or.kr/ (accessed on 1 July 2019)) (KISVALUE and DART are equivalent to COMPUSTAT and Securities and Exchange Commission in the U.S., respectively). We excluded firms whose financial or non-financial information is missing. Financial firms were also excluded for the sake of comparability. After this procedure, our data consisted of 419 firms, of which $59 \%$ were family firms. Since we constructed unbalanced panel data from 2013 to 2016, our final data comprised 1300 firmyear observations.

\subsection{Dependent Variable}

Performance: Studies have used two distinct sets of performance measures: (1) accounting-based and (2) market-based performance. The former reflects what a firm achieved in the focal year and therefore is backward-looking. The latter reflects what a firm will achieve in the future forecasted in the focal year and, accordingly, has a bearing on its business prospects and investor sentiments, rendering this measure forward-looking [92]. Because accounting-based measures of performance are often subject to manipulation like income smoothing [93-95] and cannot reflect qualitatively relevant information on the firm's business state in a timely fashion, market-based measures are arguably more precise measures of firm performance [96]. So, we opted for market-based measures in preference to accounting-based ones. Among other market performance measures, we chose the market-to-book ratio, which is operationalized as the market capitalization divided by the book value of equity $[78,97,98]$.

\subsection{Independent Variable}

Family firms: Following the prior literature, we identified a family firm on the basis of the family's stock ownership [2]. Hence, a firm does not need to have a family member as the firm's CEO to be eligible for a family firm. Regarding the cutoff value of ownership stake, there is no agreement in the literature, suggesting that the decision depends on the national context and the corporate governance system therein and therefore is an empirical question. In view of our empirical context in which corporate ownership is not adequately widely distributed and the corporate governance mechanisms are relatively weakly enforced [91], we decided to use $20 \%$ as the cutoff value. This decision is consistent with other studies such as La Porta and colleagues [2] and Villalonga and Amit [53]. Consequently, a firm in which the family retains a $20 \%$ or greater ownership stake is classified as a family firm. However, we conducted a robustness check using $5 \%$ as the cutoff value in the results section.

\subsection{Moderating Variables}

Inside CEO: This variable measures whether the incumbent CEO was internally promoted or externally hired from the outside. For this, we reviewed all the information on the CEO in the focal year by using the KISLINE database and DART (Data Analysis, 
Retrieval, and Transfer system) offered by the Korea Financial Supervisory Service (http: // dart.fss.or.kr/ (accessed on 1 July 2019)). Consistent with prior studies (Datta and Guthrie, 1994; Zhang and Rajagopalan, 2010), we coded this variable as one if the CEO is internally promoted and zero otherwise.

Business fluctuations: There are many candidates for the underlying index by which to calculate business fluctuations. Following the finance literature [96], we chose a firm's stock price as the underlying index of intrinsic value reflective of a firm's business prospect. As Turner and Wiegel stated, "any changes in the price of the risky asset are related to changing expectations regarding the asset's cash flows, time-varying required rates of return, and the degree of comovement between cash flows and discount factors" [99]. In tune with this description, we operationalized business fluctuations as a standard deviation of the focal year's daily stock price.

\subsection{Control Variables}

Firm-level attributes: We controlled for the effect of firm size on market performance by inserting the logarithm of sales. We also inserted controls for a firm's strategic investments in resources that may confound our explanation: research and development $(R \& D)$ intensity and advertising intensity, operationalized as R\&D and advertising expenditures divided by sales, respectively [100]. Plus, we inserted two organizational slack variables as controls: current ratio and debt-to-equity ratio. The former captures unabsorbed slack (or liquidity) and the latter potential slack (or leverage) [101]. These variables are operationalized as current assets divided by current liabilities and total debt divided by equity $[100,102]$. Finally, we controlled for CEO tenure. We winsorized all the ratio variables at the cutoff values of $0.5 \%$ and $99.5 \%$ to reduce abnormal behaviors of ratio variables that mostly stem from the infinitesimal denominator.

Macro-level attributes: To control for year-specific macroeconomic effects, we inserted year dummies, which were coded one for each chosen year and zero otherwise. This inclusion is crucial to our model because the estimation technique we chose requires that errors be uncorrelated across individual units [103]. In contrast, we did not include any time-constant variables or fixed effects since our estimation technique controls for them, as detailed below.

Estimation Technique:

Considering the panel data structure, we modeled our theoretical process as follows:

$$
Y_{i t}=X_{i t} \beta+\mu_{i}+\varepsilon_{i t}
$$

where $Y_{i t}$ represents economic performance, $X_{i t}$ represents a vector of covariates for firm $i$ at time $t, \mu_{i}$ represents the fixed effects or unobserved heterogeneity for firm $i$, and $\varepsilon_{i t}$ represents the random disturbance.

Notably, this model needs to address two sources of endogeneity stemming from omitted variables. For one, thanks to the panel data structure in which the same cross-sectional unit is observed multiple times, the error term violates the IID (independent and identically distributed) assumption. Therefore, to get consistent estimates, this model needs to purge the unobserved heterogeneity [104]. Nonetheless, this is not so much a drawback as it is an advantage to improve statistical consistency, given that it is difficult in cross-sectional data to get around the problem of unobserved heterogeneity. For another, this model is likely to suffer from reverse causality. In analyzing the causal relationship from ownership structure to economic performance, the central econometric concern is the endogeneity from reverse causality $[18,105]$. Unless reverse causality is controlled for, we cannot rule out the possibility that economic performance drives a certain ownership structure, not the other way around [106]. The resulting symptoms are inflated or deflated (i.e., inconsistent) coefficient estimates of the focal ownership variable. The extant literature on family firms has been relatively unsuccessful in controlling for reverse causality, rendering the empirical findings less reliable (see [20]). 
We address these two different types of endogeneity by using the Blundell and Bond [33] estimator based on the system generalized method of moments (GMM). This estimator contends with the endogeneity by instrumenting endogenous variables with predetermined and exogenous variables. Most of all, one virtue of this estimator is that all the lagged values of the covariates can be considered good candidates for valid instruments, provided that residual terms do not represent serial correlation [107-109], alleviating the difficulty of collecting external instruments [103]. What differentiates this estimator from the Arellano-Bond estimator is that this estimator further improves efficiency by employing additional moment conditions on top of the moment conditions that the Arellano-Bond estimator conventionally uses $[33,107,110]$. To incorporate the two different sets of moment conditions, this estimator utilizes the system estimation of GMM [103]. Another virtue of this estimator is that it expunges unobserved heterogeneity via first-differencing or orthogonal deviation during the estimation process [111]. Taken together, this estimator addresses the endogeneity concern confronting our econometric model mentioned above.

For estimation, we used the xtabond 2 command in STATA 15 [112]. To control for heteroskedasticity, we report robust standard errors.

\section{Results}

Table 1 exhibits descriptive statistics and correlations for all variables. To eliminate non-essential collinearity, all variables used in the interactions were mean-centered [113]. However, their descriptive statistics are reported in their original values for ease of interpretation. There were no correlation coefficients greater than 0.4, exhibiting less concern about multicollinearity. Even so, we calculated variance inflation factors (VIFs) to carefully evaluate the multicollinearity issue. The largest VIF was far below 10, with the mean VIF below 2 . Thus, the concern about multicollinearity was virtually nil.

Table 1. Descriptive statistics and correlation matrix ${ }^{\mathrm{a}, \mathrm{b}}$.

\begin{tabular}{|c|c|c|c|c|c|c|c|c|c|c|c|}
\hline & Mean & S.D. & 1 & 2 & 3 & 4 & 5 & 6 & 7 & 8 & 9 \\
\hline 1.Market-to-book ratio & 1.36 & 1.87 & & & & & & & & & \\
\hline 2.Sales ${ }^{\mathrm{b}}$ & 1.75 & 7.16 & -0.060 & & & & & & & & \\
\hline 3.R\&D intensity & 0.03 & 0.16 & 0.065 & -0.130 & & & & & & & \\
\hline 4.Advertising intensity & 0.05 & 1.33 & 0.011 & -0.136 & -0.004 & & & & & & \\
\hline 5.Current ratio & 2.64 & 4.95 & 0.020 & -0.286 & 0.000 & -0.011 & & & & & \\
\hline 6.Debt-to-equity ratio & 0.99 & 1.57 & 0.057 & 0.200 & -0.026 & -0.004 & -0.176 & & & & \\
\hline 7.CEO tenure & 9.48 & 9.40 & -0.044 & -0.235 & -0.020 & 0.010 & 0.009 & -0.083 & & & \\
\hline 8.Business Fluctuations & 0.52 & 0.34 & 0.048 & -0.020 & -0.017 & 0.014 & -0.010 & -0.044 & 0.051 & & \\
\hline 9.Inside CEO & 0.63 & 0.48 & -0.027 & 0.005 & -0.001 & 0.022 & 0.092 & -0.021 & 0.203 & -0.009 & \\
\hline 10.Family firm & 0.59 & 0.49 & -0.050 & -0.250 & -0.043 & 0.024 & 0.111 & -0.128 & 0.299 & 0.019 & -0.201 \\
\hline
\end{tabular}

${ }^{\mathrm{a}}$ Correlations of $|0.054|$ or greater are significant at $p<0.05$, and correlations of $|0.071|$ or greater are significant at $p<0.01 .{ }^{\mathrm{b}}$ in trillion Wons.

Tables 2 and 3 present the Blundell-Bond GMM estimates for the market-to-book ratio. As with other dynamic panel GMM estimates, the Blundell-Bond estimates should pass various tests to be considered consistent. First, the Arellano-Bond [114] test for AR(2) demonstrated no second-order autocorrelation of residuals (i.e., AR(2)) in our models. In the presence of $\mathrm{AR}(2)$, there is no guarantee that the lagged values can be valid instruments regardless of how long lags are taken. Second, Hansen's $J$ statistic is insignificant in all our models. This result indicates that the instruments used were jointly valid or exogenous as a whole (We carefully referred to the combination of the AR(2) test statistic, Hansen's J statistic, and difference-in-Hansen statistic to fine-tune the lag structure of instruments. We chose as instruments two- and three-year lags for our focal variables, i.e., the family dummy and its interaction terms, dependent variable, and firm control variables except for R\&D and marketing intensity for which we used three-year lags. The number of chosen instruments is far below the number of cross-sectional units; there is relatively less concern about too many instruments that can weaken the reliability of the Hansen test [103]). We also confirmed that all instrument groups were valid on the 
basis of the difference-in-Hansen test. This batch of specification tests suggests that our chosen econometric model is safe from endogeneity and generates consistent parameter estimates $[103,111,115]$.

Table 2. Blundell-Bond system generalized method of moments (GMM) estimates for market-to-book ratio ${ }^{\mathrm{a}, \mathrm{b}, \mathrm{c}}$.

\begin{tabular}{|c|c|c|c|c|}
\hline & \multicolumn{4}{|c|}{ Family Firm = Family Ownership $>20 \%$} \\
\hline & (1) & (2) & (3) & (4) \\
\hline Constant & $\begin{array}{l}6.694 * \\
(2.960)\end{array}$ & $\begin{array}{l}6.360 * \\
(2.906)\end{array}$ & $\begin{array}{l}6.255^{*} \\
(3.023)\end{array}$ & $\begin{array}{l}9.837^{*} \\
(4.388)\end{array}$ \\
\hline Sales $_{t}$ & $\begin{array}{c}-0.369+ \\
(0.210)\end{array}$ & $\begin{array}{l}-0.341 \\
(0.209)\end{array}$ & $\begin{array}{c}-0.366+ \\
(0.218)\end{array}$ & $\begin{array}{l}-0.380 \\
(0.241)\end{array}$ \\
\hline$R \& D$ intensity $t$ & $\begin{array}{c}-1.140+ \\
(0.651)\end{array}$ & $\begin{array}{c}-1.132+ \\
(0.661)\end{array}$ & $\begin{array}{c}-1.257+ \\
(0.754)\end{array}$ & $\begin{array}{c}-0.970 \\
(0.757)\end{array}$ \\
\hline Advertising intensity $_{t}$ & $\begin{array}{c}0.005 \\
(0.082)\end{array}$ & $\begin{array}{c}0.008 \\
(0.081)\end{array}$ & $\begin{array}{l}-0.001 \\
(0.076)\end{array}$ & $\begin{array}{c}0.009 \\
(0.091)\end{array}$ \\
\hline Current ratiot & $\begin{array}{c}-0.008 \\
(0.024)\end{array}$ & $\begin{array}{c}-0.009 \\
(0.025)\end{array}$ & $\begin{array}{l}-0.010 \\
(0.025)\end{array}$ & $\begin{array}{c}-0.009 \\
(0.027)\end{array}$ \\
\hline Debt-to-equity ratio $_{t}$ & $\begin{array}{c}0.134^{* * *} \\
(0.038)\end{array}$ & $\begin{array}{c}0.136^{* * *} \\
(0.038)\end{array}$ & $\begin{array}{l}0.123 * * \\
(0.042)\end{array}$ & $\begin{array}{c}0.167^{* * *} \\
(0.047)\end{array}$ \\
\hline $\mathrm{CEO}_{\text {tenure }}$ & $\begin{array}{l}-0.426 \\
(0.383)\end{array}$ & $\begin{array}{c}-0.485 \\
(0.444)\end{array}$ & $\begin{array}{l}-0.544 \\
(0.442)\end{array}$ & $\begin{array}{l}-0.656 \\
(0.419)\end{array}$ \\
\hline Business fluctuations $s_{t}(C)$ & $\begin{array}{c}0.466 \\
(0.672)\end{array}$ & $\begin{array}{c}0.364 \\
(0.664)\end{array}$ & $\begin{array}{c}0.575 \\
(0.698)\end{array}$ & $\begin{array}{c}-4.679 * \\
(2.368)\end{array}$ \\
\hline Inside $\mathrm{CEO}_{\mathrm{t}}(\mathrm{B})$ & $\begin{array}{l}-0.087 \\
(0.617)\end{array}$ & $\begin{array}{l}-0.156 \\
(0.591)\end{array}$ & $\begin{array}{c}0.766 \\
(1.058)\end{array}$ & $\begin{array}{c}-3.822 \text { * } \\
(1.923)\end{array}$ \\
\hline Family firm $(\mathrm{A})$ & & $\begin{array}{c}0.345 \\
(0.635)\end{array}$ & $\begin{array}{c}0.979 \\
(0.842)\end{array}$ & $\begin{array}{c}-3.355^{*} \\
(1.692)\end{array}$ \\
\hline (A) $X(B)$ & & & $\begin{array}{l}-1.196 \\
(1.169)\end{array}$ & $\begin{array}{l}4.662 * \\
(2.226)\end{array}$ \\
\hline (B) $X(C)$ & & & & $\begin{array}{l}6.781 * \\
(3.395)\end{array}$ \\
\hline (A) $X(C)$ & & & & $\begin{array}{l}6.328^{*} \\
(3.056)\end{array}$ \\
\hline (A) $X(B) X(C)$ & & & & $\begin{array}{c}-7.782 \text { * } \\
(3.759)\end{array}$ \\
\hline Observations & 1300 & 1300 & 1300 & 1300 \\
\hline Number of firms & 419 & 419 & 419 & 419 \\
\hline Number of instruments & 157 & 157 & 235 & 339 \\
\hline $\operatorname{ar}(2)$ & 0.903 & 0.926 & 0.897 & 0.298 \\
\hline Hansen J statistic & 62.74 & 59.29 & 59.47 & 64.93 \\
\hline Hansen J statistic's $p$-value & 0.689 & 0.765 & 0.854 & 0.939 \\
\hline Chi-squared statistic & $554.5^{* * *}$ & $547.2 * * *$ & $532.5^{* * *}$ & $441.4^{* * *}$ \\
\hline
\end{tabular}

a robust standard errors in parentheses. ${ }^{\mathrm{b}}$ year dummies included but not reported. ${ }^{\mathrm{c} * * *} p<0.001,{ }^{* *} p<0.01$, * emphp $<0.05,+p<0.1$.

Table 2 presents the Blundell-Bond GMM estimates when we use $20 \%$ family stock ownership as the cutoff value to identify family firms. Model 1 is a baseline model that includes control variables only. Surprisingly, sales have a negative effect on the market-tobook ratio in our sample if the endogeneity is controlled. This may indicate that the firms in our sample that are relatively big operate in the region of scale diseconomies [116] or that the firms are mature and in want of new and promising investment opportunities. Another interesting point is that $R \& D$ intensity also impinges negatively on the market performance. This may suggest that R\&D activities conducted by our sample firms are not productive enough to generate values greater than costs. Plus, financial leverage (i.e., debt-to-equity ratio) has a strong positive effect on the market performance, supporting Jensen's [117] view that debt drives organizational efficiency. 
Model 2 inserts the family firm dummy, our focal variable; model 3 introduces the internally-promoted CEO hypothesized to moderate the relationship between the family firm dummy and performance; and model 4 additionally inserts three-way-interaction terms of the family firm dummy, the internally-promoted CEO, and business fluctuations, together with the other two two-way interactions aimed to rule out spurious explanations [113]. According to the results, we find support for hypothesis 1 that examines the effect of family firms on performance in model 4 in which all main effects and moderating effects are factored $(\beta=-3.355, p<0.05)$. The fact that hypothesis 1 is supported only in the full model indicates that our theorized moderators are in operation, masking the relationship of hypothesis 1 . As before, we find support for hypothesis 2 only in the full model $(\beta=4.662$ at $p<0.05)$. In a similar vein, this result implies that without controlling for the moderating effect of business fluctuations on the moderating effect of inside CEOs, the moderating effect of inside CEOs is not empirically observable. Finally, we also find support for hypothesis $3(\beta=-7.782$ at $p<0.05)$ in model 4 , the full model.

\subsection{Post Hoc Analysis}

To better understand the practical implications, we offer a graphical representation of moderating results in which we use values one standard deviation above and below the mean for the continuous interacting variables, and zero and one for the dichotomous variables. For these figures, we use the regression result of model 4 in Table 2. In Figure 1, we show the moderating effect of outside CEOs on the relationship between firm types and the market-to-book ratio. A leadership change from inside CEOs to outside CEOs in family firms precipitously reduces the market-to-book ratio from 4.14 to 1.27. Contrarily, the change in non-family firms increases the market-to-book ratio from 1.04 to 1.31 . Thus, family firms managed by inside CEOs outperform non-family firms, whereas those managed by outside CEOs underperform the non-family firms managed by outside CEOs. As such, inside CEOs successfully nurture and manage family firms, whereas outside CEOs destroy the value of family firms.

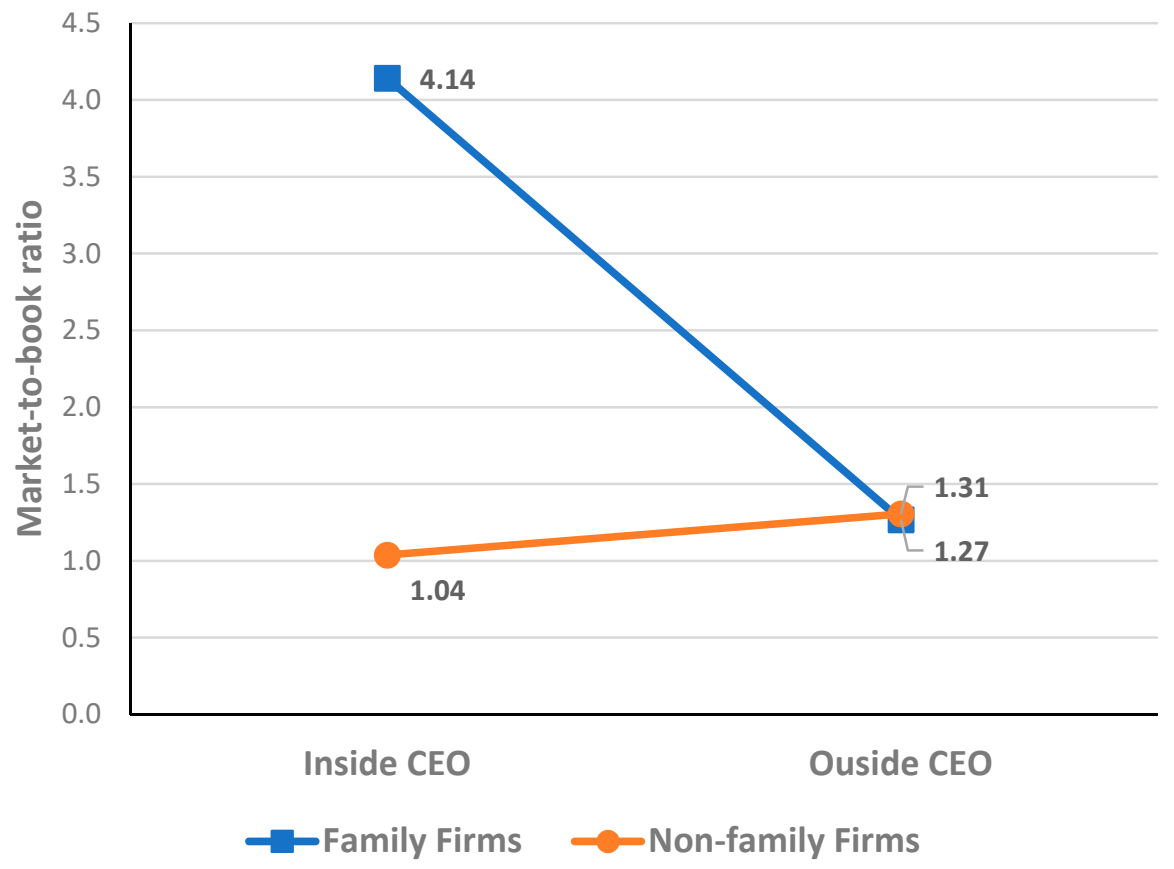

Figure 1. Interaction of firm types and CEO types on performance.

In Figure 2, we exhibit the effect of business fluctuations on the moderating effect of inside CEOs on the relationship between family firms and the market-to-book ratio. Family firms managed by inside CEOs outperform those managed by outside CEOs by a large 
margin $(0.66=1.36-0.70)$ when their business fluctuations are small. On the contrary, when their business fluctuations grow larger, family firms managed by inside CEOs fall behind those managed by outside CEOs. Therefore, both graphs confirm that the moderators shift the theorized relationship in the predicted directions within the data range of our sample.

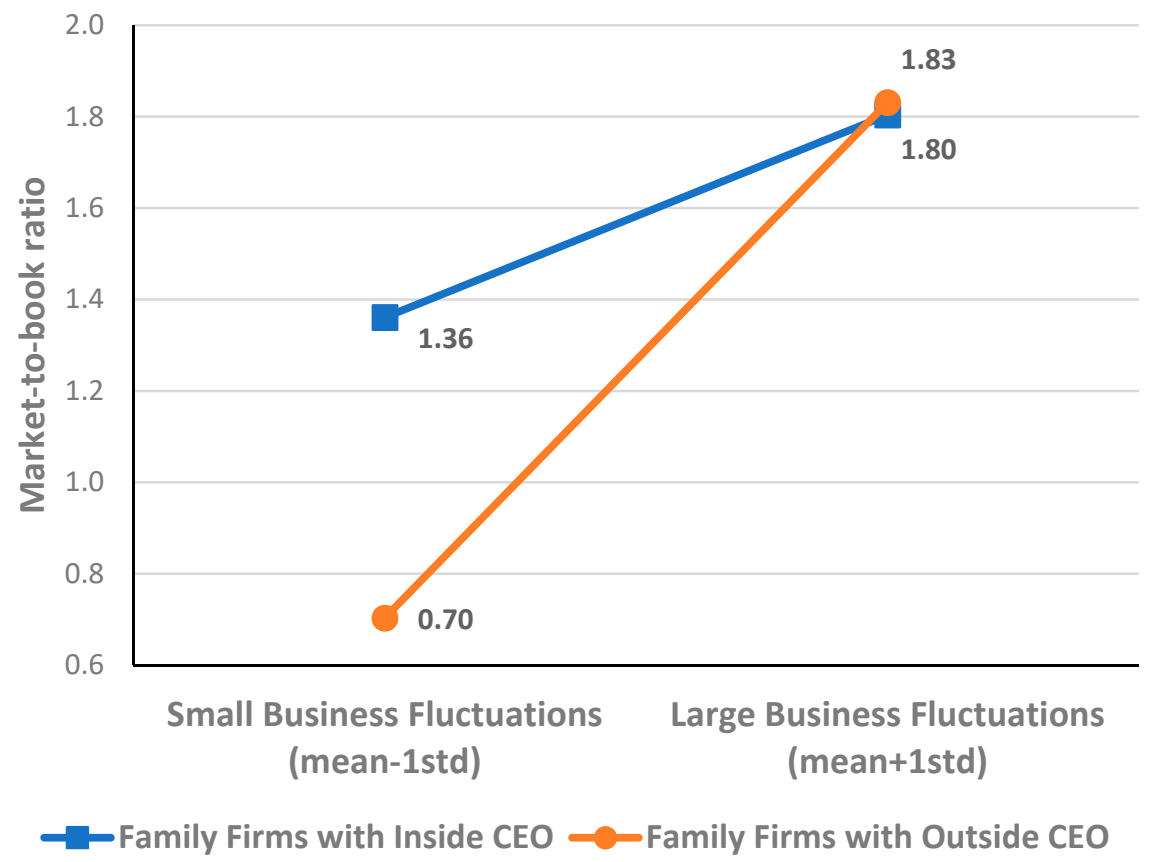

Figure 2. Interaction of CEO types and business fluctuations on performance in family firms.

\subsection{Robustness Check}

Given that there is no consensus on the cutoff value that distinguishes family firms from non-family firms, we conducted a robustness check by employing $5 \%$ family stock ownership instead as the cutoff value. As the familiness arguably increases with stock ownership, this robustness check should be considered a kind of conservative test. The results were presented in the Table A1 in the Appendix A. As before, all the specification tests were passed in all models, ensuring that the estimates are immune to endogeneity. The results pattern remains almost similar, although the significance level of our focal variables dwindles a little. This is not surprising given that the familiness is likely weaker in this test, diluting the previous results.

\subsection{Evaluation of Endogeneity Based on Various Econometric Techniques}

To evaluate the influence of endogeneity on our results, we conducted additional analyses of the full model by using OLS (ordinary least squares), the random-effects (RE) estimator, and the fixed-effects (FE) estimator and compared their estimates with the Blundell and Bond (BB) estimates in Table 3. OLS employs the restrictive Gauss-Markov assumptions; RE relaxes the assumption of non-autocorrelation; FE relaxes the assumption of exogeneity of unobserved effects; BB further relaxes the assumption of exogeneity of covariates in addition to the unobserved effects [106]. Thus, the results may be viewed as exhibiting how the estimates change as the Gauss-Markov assumptions are relaxed one by one (for this, we conducted a poolability test for the choice between OLS and panel regressions and the Hausman specification test for the choice between RE and FE. For the poolability test, we conducted a joint $\mathrm{F}$ test of the fixed effects. According to the result, the null hypothesis that all the fixed effects are zero is rejected at $p<0.001$, in favor of panel regressions. The Hausman specification test result rejects the null hypothesis that RE is an efficient and consistent estimator of the true parameters at $p<0.001$, in favor of FE). The results pattern was relatively similar, and the coefficients of family 
firms were all negative regardless of which estimators were used. Notably, however, the coefficients of OLS and RE estimates were insignificant, while those of FE and BB estimates in which the fixed effects are controlled for were significant at $p<0.1$ and $p<0.05$, respectively. This difference indicates that the endogeneity derives partly from the fixed effects (or unobserved heterogeneity). The coefficient of the BB estimates was much greater and more significant than that of the FE estimates, implying that the endogeneity also stems from time-varying effects. We view the two effects, both arising from omitted variables, as reflective of the reverse causality that counteracts our theorized effect in the opposite direction [18]. In other words, the family tends to maintain its firm if the firm has promising prospects. Conversely, it tends to sell its firm or stock ownership at a minimum if the firm is anticipated not to hold promise in the future. In conclusion, these results join the view calling attention to the fact that the endogeneity control is critical in analyzing the effect of corporate ownership in general and family involvement in particular on performance [18-20].

Table 3. Comparison of estimates across estimators ${ }^{a, b, c}$.

\begin{tabular}{|c|c|c|c|c|}
\hline & OLS & RE & FE & BB \\
\hline & (1) & (2) & (3) & (4) \\
\hline \multirow{2}{*}{ Constant } & $2.734 * *$ & $2.808^{* *}$ & 3.392 & $9.837 *$ \\
\hline & $(0.905)$ & $(1.044)$ & $(3.932)$ & $(4.388)$ \\
\hline \multirow{2}{*}{ Sales $_{t}$} & $-0.089 *$ & $-0.086+$ & -0.046 & -0.380 \\
\hline & $(0.044)$ & $(0.052)$ & $(0.281)$ & $(0.241)$ \\
\hline \multirow{2}{*}{ R\&D intensity $t$} & $0.688 *$ & $0.482+$ & -0.051 & -0.970 \\
\hline & $(0.296)$ & $(0.256)$ & $(0.349)$ & $(0.757)$ \\
\hline \multirow{2}{*}{ Advertising intensity $_{t}$} & -0.001 & -0.007 & -0.007 & 0.009 \\
\hline & $(0.008)$ & $(0.009)$ & $(0.052)$ & $(0.091)$ \\
\hline \multirow{2}{*}{ Current ratio $t$} & 0.006 & 0.008 & 0.003 & -0.009 \\
\hline & $(0.012)$ & $(0.014)$ & $(0.015)$ & $(0.027)$ \\
\hline \multirow{2}{*}{ Debt-to-equity ratio ${ }_{t}$} & $0.084^{* * *}$ & $0.096^{* * *}$ & $0.266^{*}$ & $0.167^{* * *}$ \\
\hline & $(0.024)$ & $(0.024)$ & $(0.126)$ & $(0.047)$ \\
\hline \multirow{2}{*}{$\mathrm{CEO}_{\text {tenure }} \mathrm{t}_{\mathrm{H}}$} & -0.097 & -0.090 & -0.164 & -0.656 \\
\hline & $(0.076)$ & $(0.089)$ & $(0.177)$ & $(0.419)$ \\
\hline \multirow{2}{*}{ Business fluctuations $_{t}(\mathrm{C})$} & 0.171 & -0.068 & -1.325 & -4.679 * \\
\hline & $(0.420)$ & $(0.509)$ & $(0.923)$ & $(2.368)$ \\
\hline \multirow{2}{*}{ Inside $\mathrm{CEO}_{\mathrm{t}}(\mathrm{B})$} & -0.143 & -0.283 & -1.391 & -3.822 * \\
\hline & $(0.355)$ & $(0.406)$ & $(0.924)$ & (1.923) \\
\hline \multirow{2}{*}{ Family firm $_{t}(\mathrm{~A})$} & -0.567 & -0.618 & $-0.952+$ & $-3.355^{*}$ \\
\hline & $(0.348)$ & $(0.399)$ & $(0.525)$ & $(1.692)$ \\
\hline \multirow{2}{*}{ (A) $X(B)$} & 0.482 & 0.576 & 0.804 & $4.662 *$ \\
\hline & $(0.396)$ & $(0.437)$ & $(0.767)$ & $(2.226)$ \\
\hline \multirow{2}{*}{ (B) $X(C)$} & 0.030 & 0.244 & 1.017 & $6.781 *$ \\
\hline & $(0.562)$ & $(0.635)$ & $(1.060)$ & (3.395) \\
\hline \multirow{2}{*}{ (A) $X(C)$} & 0.506 & 0.599 & 1.186 & $6.328 *$ \\
\hline & $(0.533)$ & $(0.584)$ & $(1.037)$ & $(3.056)$ \\
\hline \multirow{2}{*}{$(\mathrm{A}) \mathrm{X}(\mathrm{B}) \mathrm{X}(\mathrm{C})$} & -0.515 & -0.650 & -0.865 & $-7.782 *$ \\
\hline & $(0.675)$ & $(0.708)$ & $(1.174)$ & $(3.759)$ \\
\hline Observations & 1300 & 1300 & 1300 & 1300 \\
\hline F-statistic & $9.510 * * *$ & - & $124.7^{* * *}$ & - \\
\hline Chi-squared statistic & - & $198.4^{* * *}$ & - & $441.4^{* * *}$ \\
\hline
\end{tabular}

a robust standard errors in parentheses. ${ }^{\mathrm{b}}$ year dummies included but not reported. ${ }^{\mathrm{c} * * *} p<0.001,{ }^{* *} p<0.01$, ${ }^{*} p<0.05,+p<0.1$.

\section{Discussion and Conclusions}

Due to their tremendous economic influence, family firms have received considerable scholarly attention. An impressive amount of research efforts has been devoted to determining whether the family as a corporate owner is a paragon or a parasite. Unfortunately, as yet, there is no telltale sign of an agreement on their impact on economic performance, 
competitive advantage, and ultimately economic sustainability. Recently, the evolving body of literature has begun to shed light on the distinct as well as contingent nature of the family as a corporate owner. The literature argues that unlike the other types of corporate owners, the family gives top priority to its socioemotional wealth preservation. Defined as "non-financial aspects of the firm that meet the family's affective needs, such as identity, the ability to exercise family influence, and the perpetuation of the family dynasty" [36], socioemotional wealth does not have a single reference to economic performance, which renders the performance implications of family involvement inevitably indeterminate and contingent on other factors regulating the penchant for socioemotional wealth preservation.

Although theoretically taking a diverse perspective, this study joins and champions this contingency view to family firms and offers a more accurate and nuanced understanding of family firms by delving into interactions among family involvement, inside CEOs, and business fluctuations. To the best of our knowledge, no studies have examined the combined effect of inside CEOs vis-à-vis outside CEOs and business uncertainty on family firms' performance implications via the three-way interaction. More importantly, our results showing that the focal two-way interaction gets significant only if the three-way interaction is introduced suggest that the contingencies deemed to regulate family behavior could be more complicated than previously thought. Similarly, we can find significance in the main effect of family involvement on market performance only when we factor in the three-way interaction. Taken together, our results demonstrate that unless appropriate contingencies (the three-way interaction in our study) are carefully chosen and controlled for, not just the main effect but also moderating effects can be masked, creating type II errors. In this regard, our results caution against deriving empirical conclusions without taking into account the contingencies requisite to understanding family firm behaviors.

Above all, we offer an answer to the long-debated question of whether the family enhances firm performance in the Korean context. Using an advanced econometric technique capable of addressing endogeneity, we find that family involvement hurts firm performance in our empirical context. In other words, the Korean economy is dragged behind by the family that commands a majority of corporate control in our sample (about $59 \%$ ). While there are many conceivable reasons for this finding, the upshot is that the family is liable to pursue non-financial goals, steering in the strategically wrong direction and offsetting the benefits it also brings.

Nonetheless, this is not the end of the story. It is worth noting that the above negative effect of family involvement is just a partial effect: a portion of the effect left after all other contingent effects are partialled out $[106,113]$. To have a more complete understanding, we analyze it in tandem with the contingencies. Interestingly, according to our post hoc analysis, family firms outperform non-family firms as long as they are managed by inside CEOs who are knowledgeable about every detail of their firms, not to mention the firms' valuable resources and capabilities not readily observable by outsiders. Therefore, the family still has a chance to contribute to its firms by having inside CEOs instead of outside ones. However, this decision may not work as expected when firms undergo substantial business fluctuations because outside CEOs have diverse knowledge and information and external networks more pertinent to dealing with such situations.

We also empirically contribute to the literature by offering a glimpse into the extent to which endogeneity biases the results. By comparing estimates from various econometric methods, we show that a non-trivial portion of endogeneity comes from fixed effects or unobserved heterogeneity. Even so, the fixed-effects estimator cannot address all the endogeneity inasmuch as the varying portion of residuals can also bear endogeneity. In this regard, our results advise that more advanced econometric techniques based on the instrumental variable estimation or generalized method of moments and capable of handling fixed effects should be opted for to get consistent estimates.

Finally, we bring into focus family firms as a crucial agent for determining economic sustainability. Given that family firms account for a substantial fraction of economic activity, their sustainability nontrivially contributes to a country's economic sustainability, albeit 
not in a linear summation fashion. As Ronald Coase [118], a Nobel laureate, elucidated, firms exist because they are more efficient than the market at organizing and transforming economic resources into outputs. So viewed, economic sustainability, in a sense, is encapsulated in the never-ending race toward resource allocative efficiency between the two fundamental forms of economic institutions: firms and the market. The family has a non-negligible say in this race by decidedly determining the efficiency of firms as a whole. In this respect, this study calls attention to family firms as a significant player in the analysis of economic sustainability.

\section{Limitations and Future Research}

As with other studies, this one is not without limitations. First, this study utilizes single-country data. While using a single-country setting is advantageous to controlling for other confounders at the national level, such as institutional variance, its downside is that so-derived results may not be generalizable to other countries. Thus, there is a need for further research to validate our findings in other countries. Second, we confine our analysis to relatively large firms listed on the stock market. It could be that our theory and results may not hold in small and medium-sized firms. We believe that future research could benefit from investigating these small and medium-sized firms in extending our knowledge of family firms. Third, our sample period may be too short to be robust against spurious explanations and some statistical concerns. Even if our test results showed less concern about a spurious explanation based on environmental conditions, there could have been another environmental dimension that was different between the two periods and thereby might have confounded our empirical results. Moreover, the long-time panel is better for the statistical consistency of estimates. Future studies may benefit from reassessing our theory using longer-term panel data. Similarly, the long-time panel is better for the statistical consistency of estimates. Future studies may benefit from reassessing our theory using longer-term panel data. Finally, we use a relatively arbitrary cutoff value when identifying family firms. Even though this cutoff value is widely used and we also conduct a robustness check using another cutoff value, the ownership effects on performance may not be linear [119]. Future studies would benefit from exploring the potentially nonlinear effect of family ownership by considering various cutoff values bracketing arguably varying family effects according to ownership.

Author Contributions: K.J. (conceptualization, theory development, methodology, writing-original draft, project administration, funding acquisition); J.L. (conceptualization, investigation, data collection, writing-review and editing); S.M.H. (conceptualization, investigation, data collection). All authors have read and agreed to the published version of the manuscript.

Funding: This work was supported by GIST Research Institute (GRI) grant funded by the GIST in 2021 .

Institutional Review Board Statement: Not applicable.

Informed Consent Statement: Not applicable.

Data Availability Statement: The data will be made available on request from the corresponding author.

Acknowledgments: We gratefully acknowledge research assistance by Jun Su You.

Conflicts of Interest: The authors declare no conflict of interest. 


\section{Appendix A}

Table A1. Blundell-Bond System GMM Estimates for Market-to-book Ratio When 5\% Cutoff Value Is Used $^{\mathrm{a}, \mathrm{b}, \mathrm{c}}$.

\begin{tabular}{|c|c|c|c|c|}
\hline & \multicolumn{4}{|c|}{ Family Firm = Family Ownership $>5 \%$} \\
\hline & (5) & (5) & (6) & (7) \\
\hline \multirow{2}{*}{ Constant } & $6.694 *$ & 5.834 * & $5.792 *$ & $7.901 *$ \\
\hline & $(2.960)$ & $(2.899)$ & $(2.796)$ & $(3.686)$ \\
\hline \multirow{2}{*}{ Salest } & $-0.369+$ & -0.310 & -0.286 & -0.223 \\
\hline & $(0.210)$ & $(0.208)$ & $(0.205)$ & $(0.260)$ \\
\hline \multirow{2}{*}{$R \& D$ intensity $t$} & $-1.140+$ & $-1.120+$ & -1.045 & -0.822 \\
\hline & $(0.651)$ & $(0.666)$ & $(0.665)$ & $(0.788)$ \\
\hline \multirow{2}{*}{ Advertising intensity $t$} & 0.005 & 0.015 & 0.019 & 0.039 \\
\hline & $(0.082)$ & $(0.084)$ & $(0.086)$ & $(0.101)$ \\
\hline \multirow{2}{*}{ Current ratio $t$} & -0.008 & -0.008 & -0.008 & -0.003 \\
\hline & $(0.024)$ & $(0.025)$ & $(0.025)$ & $(0.028)$ \\
\hline \multirow{2}{*}{ Debt-to-equity ratio $t$} & $0.134^{* * *}$ & $0.143^{* * *}$ & $0.152 * * *$ & $0.138^{* * *}$ \\
\hline & $(0.038)$ & $(0.040)$ & $(0.036)$ & $(0.037)$ \\
\hline \multirow{2}{*}{ CEO tenure $_{t}$} & -0.426 & -0.512 & -0.562 & -0.620 \\
\hline & $(0.383)$ & $(0.432)$ & $(0.429)$ & $(0.420)$ \\
\hline \multirow{2}{*}{ Business fluctuationst $(\mathrm{C})$} & 0.466 & 0.306 & 0.454 & -5.535 * \\
\hline & $(0.672)$ & $(0.657)$ & $(0.665)$ & $(2.617)$ \\
\hline \multirow{2}{*}{ Inside $\mathrm{CEO}_{\mathrm{t}}(\mathrm{B})$} & -0.087 & -0.142 & -0.709 & -4.043 * \\
\hline & $(0.617)$ & $(0.601)$ & $(0.631)$ & $(1.710)$ \\
\hline \multirow{2}{*}{ Family firm $(\mathrm{A})$} & & 0.583 & 0.079 & -2.512 \\
\hline & & $(0.650)$ & $(0.777)$ & $(2.045)$ \\
\hline (A) $X(B)$ & & & $\begin{array}{c}0.943 \\
(0.793)\end{array}$ & $\begin{array}{l}4.099+ \\
(2.426)\end{array}$ \\
\hline & & & $(0.193)$ & $7.582 *$ \\
\hline (B) $X(C)$ & & & & $(3.555)$ \\
\hline (A) $\times(C)$ & & & & 5.350 \\
\hline (A) X (C) & & & & $(3.655)$ \\
\hline (A) $X(B) \times(C)$ & & & & -6.942 \\
\hline (A) $\times($ B) $\times(C)$ & & & & $(4.711)$ \\
\hline Observations & 1300 & 1300 & 1300 & 1300 \\
\hline Number of firms & 419 & 419 & 419 & 419 \\
\hline Number of instruments & 157 & 157 & 235 & 339 \\
\hline $\operatorname{ar}(2)$ & 0.903 & 0.948 & 0.923 & 0.136 \\
\hline Hansen J statistic & 62.74 & 58.01 & 58.15 & 69.68 \\
\hline Hansen J statistic's p-value & 0.689 & 0.801 & 0.881 & 0.869 \\
\hline Chi-squared statistic & $554.5^{* * *}$ & $538.0 * * *$ & $534.8^{* * *}$ & $495.4^{* * *}$ \\
\hline
\end{tabular}

\section{References}

1. Gersick, K.E.; Davis, J.A.; Hampton, M.M.; Lansberg, I. Generation to Generation: Life Cycles of the Family Business; Harvard Business Press: Brighton, UK, 1997; ISBN 1-4221-4342-2.

2. La Porta, R.; Lopez-de-Silanes, F.; Shleifer, A. Corporate Ownership around the World. J. Financ. 1999, 54, 471-517. [CrossRef]

3. Neubauer, F.; Lank, A. The Family Business: Its Governance for Sustainability; Macnillan: London, UK, 1998.

4. Astrachan, J.H.; Shanker, M.C. Family Businesses' Contribution to the U.S. Economy: A Closer Look. Fam. Bus. Rev. 2003, 16, 211-219. [CrossRef]

5. Doane, D.; MacGillivray, A. Economic Sustainability: The Business of Staying in Business. N. Econ. Found. 2001, 1-52.

6. Spangenberg, J.H. Economic sustainability of the economy: Concepts and indicators. Int. J. Sustain. Dev. 2005, 8, 47. [CrossRef]

7. Amit, R.; Villalonga, B. Financial Performance of Family Firms. SAGE Handb. Fam. Bus. 2014, 157-178. [CrossRef]

8. Chrisman, J.J.; Chua, J.H.; Kellermanns, F. Priorities, Resource Stocks, and Performance in Family and Nonfamily Firms. Entrep. Theory Pr. 2009, 33, 739-760. [CrossRef]

9. Dyer, W.G. Examining the "Family Effect" on Firm Performance. Fam. Bus. Rev. 2006, 19, 253-273. [CrossRef] 
10. O'Boyle, E.H.; Pollack, J.M.; Rutherford, M.W. Exploring the relation between family involvement and firms' financial performance: A meta-analysis of main and moderator effects. J. Bus. Ventur. 2012, 27, 1-18. [CrossRef]

11. Allouche, J.; Amann, B.; Jaussaud, J.; Kurashina, T. The Impact of Family Control on the Performance and Financial Characteristics of Family Versus Nonfamily Businesses in Japan: A Matched-Pair Investigation. Fam. Bus. Rev. 2008, 21, 315-330. [CrossRef]

12. Anderson, R.C.; Reeb, D.M. Founding-Family Ownership and Firm Performance: Evidence from the S\&P 500. J. Financ. 2003, 58, 1301-1328. [CrossRef]

13. Berrone, P.; Cruz, C.; Gomez-Mejia, L.R.; Larraza-Kintana, M. Socioemotional Wealth and Corporate Responses to Insti-tutional Pressures: Do Family-Controlled Firms Pollute Less? Admin. Sci. Quart. 2010, 55, 82-113. [CrossRef]

14. Chen, S.; Chen, X.; Cheng, Q.; Shevlin, T. Are Family Firms More Tax Aggressive than Non-Family Firms? J. Financ. Econ. 2010, 95, 41-61. [CrossRef]

15. Anderson, R.C.; Reeb, D.M. Board Composition: Balancing Family Influence in S\&P 500 Firms. Adm. Sci. Q. 2004, 49, $209-237$.

16. Wang, D. Founding Family Ownership and Earnings Quality. J. Account. Res. 2006, 44, 619-656. [CrossRef]

17. Sánchez-Ballesta, J.P.; García-Meca, E. A Meta-Analytic Vision of the Effect of Ownership Structure on Firm Performance. Corp. Gov. Int. Rev. 2007, 15, 879-892. [CrossRef]

18. Demsetz, H.; Lehn, K. The Structure of Corporate Ownership: Causes and Consequences. J. Political Econ. 1985, 93, 1155-1177. [CrossRef]

19. Jin, K.; Park, C. Separation of Cash Flow and Voting Rights and Firm Performance in Large Family Business Groups in Korea. Corp. Gov. Int. Rev. 2015, 23, 434-451. [CrossRef]

20. Wang, K.; Shailer, G. Ownership Concentration and Firm Performance in Emerging Markets: A Meta-Analysis. J. Econ. Surv. 2015, 29, 199-229. [CrossRef]

21. Chirico, F.; Salvato, C. Knowledge Internalization and Product Development in Family Firms: When Relational and Affective Factors Matter. Entrep. Theory Pract. 2016, 40, 201-229. [CrossRef]

22. De Massis, A.; Frattini, F.; Kotlar, J.; Petruzzelli, A.M.; Wright, M. Innovation Through Tradition: Lessons from Innovative Family Businesses and Directions for Future Research. Acad. Manag. Perspect. 2016, 30, 93-116. [CrossRef]

23. Laforet, S. Organizational innovation outcomes in SMEs: Effects of age, size, and sector. J. World Bus. 2013, 48, 490-502. [CrossRef]

24. Patel, P.C.; Fiet, J.O. Knowledge Combination and the Potential Advantages of Family Firms in Searching for Opportunities. Entrep. Theory Pr. 2011, 35, 1179-1197. [CrossRef]

25. Bertrand, M.; Schoar, A. The Role of Family in Family Firms. J. Econ. Perspect. 2006, 20, 73-96. [CrossRef]

26. Habbershon, T.G.; Pistrui, J. Enterprising Families Domain: Family-Influenced Ownership Groups in Pursuit of Transgenerational Wealth. Fam. Bus. Rev. 2002, 15, 223-237. [CrossRef]

27. Gomez-Mejia, L.R.; Cruz, C.; Berrone, P.; de Castro, J. The Bind that Ties: Socioemotional Wealth Preservation in Family Firms. Acad. Manag. Ann. 2011, 5, 653-707. [CrossRef]

28. Calabrò, A.; Campopiano, G.; Basco, R. Principal-Principal Conflicts and Family Firm Growth: The Moderating Role of Business Family Identity. J. Fam. Bus. Manag. 2017, 7, 291-308. [CrossRef]

29. Hansen, C.; Block, J. Exploring the relation between family involvement and firms' financial performance: A replication and extension meta-analysis. J. Bus. Ventur. Insights 2020, 13, e00158. [CrossRef]

30. Chrisman, J.J.; Chua, J.H.; Litz, R.A. Comparing the Agency Costs of Family and Non-Family Firms: Conceptual Issues and Exploratory Evidence. Entrep. Theory Pr. 2004, 28, 335-354. [CrossRef]

31. Kim, U.; Park, Y.-S. Confucianism and family values. Z. Erzieh. 2000, 3, 229-249. [CrossRef]

32. Park, I.H.; Cho, L.-J. Confucianism and the Korean Family. J. Comp. Fam. Stud. 1995, 26, 117-134. [CrossRef]

33. Blundell, R.; Bond, S. Initial conditions and moment restrictions in dynamic panel data models. J. Econ. 1998, 87, 115-143. [CrossRef]

34. Sirmon, D.G.; Hitt, M.A. Managing Resources: Linking Unique Resources, Management, and Wealth Creation in Family Firms. Entrep. Theory Pr. 2003, 27, 339-358. [CrossRef]

35. Habbershon, T.G.; Williams, M.L. A Resource-Based Framework for Assessing the Strategic Advantages of Family Firms. Fam. Bus. Rev. 1999, 12, 1-25. [CrossRef]

36. Gómez-Mejía, L.R.; Haynes, K.T.; Núñez-Nickel, M.; Jacobson, K.J.L.; Moyano-Fuentes, J. Socioemotional Wealth and Business Risks in Family-controlled Firms: Evidence from Spanish Olive Oil Mills. Adm. Sci. Q. 2007, 52, 106-137. [CrossRef]

37. Gomez-Mejia, L.R.; Makri, M.; Kintana, M.L. Diversification Decisions in Family-Controlled Firms. J. Manag. Stud. 2010, 47, 223-252. [CrossRef]

38. Herrero, I. Agency Costs, Family Ties, and Firm Efficiency. J. Manag. 2011, 37, 887-904. [CrossRef]

39. Jones, G.R. Transaction Costs, Property Rights, and Organizational Culture: An Exchange Perspective. Adm. Sci. Q. 1983, $28,454$. [CrossRef]

40. Eddleston, K.A.; Morgan, R.M. Trust, commitment and relationships in family business: Challenging conventional wisdom. J. Fam. Bus. Strat. 2014, 5, 213-216. [CrossRef]

41. Eddleston, K.A.; Chrisman, J.J.; Steier, L.P.; Chua, J.H.; Chua, J.H. Governance and Trust in Family Firms: An Introduction. Entrep. Theory Pr. 2010, 34, 1043-1056. [CrossRef]

42. Davis, J.H.; Allen, M.R.; Hayes, H.D. Is Blood Thicker Than Water? A Study of Stewardship Perceptions in Family Business. Entrep. Theory Pr. 2010, 34, 1093-1116. [CrossRef] 
43. James, H.S. Owner as Manager, Extended Horizons and the Family Firm. Int. J. Econ. Bus. 1999, 6, 41-55. [CrossRef]

44. Arregle, J.-L.; Hitt, M.A.; Sirmon, D.G.; Very, P. The Development of Organizational Social Capital: Attributes of Family Firms. J. Manag. Stud. 2007, 44, 73-95. [CrossRef]

45. Kellermanns, F.W.; Eddleston, K.A.; Barnett, T.; Pearson, A. An Exploratory Study of Family Member Characteristics and Involvement: Effects on Entrepreneurial Behavior in the Family Firm. Fam. Bus. Rev. 2008, 21, 1-14. [CrossRef]

46. Nahapiet, J.; Ghoshal, S. Social Capital, Intellectual Capital, and the Organizational Advantage. Acad. Manag. Rev. 1998, 23, 242-266. [CrossRef]

47. Coleman, J.S. Social Capital in the Creation of Human Capital. Netw. Knowl. Econ. 2003, 94, 95. [CrossRef]

48. Lin, N. Social Capital: A Theory of Social Structure and Action; Cambridge University Press: Cambridge, MA, USA, 2002.

49. Olson, P.D.; Zuiker, V.S.; Danes, S.M.; Stafford, K.; Heck, R.K.; A Duncan, K. The impact of the family and the business on family business sustainability. J. Bus. Ventur. 2003, 18, 639-666. [CrossRef]

50. Ward, J.L. Growing the Family Business: Special Challenges and Best Practices. Fam. Bus. Rev. 1997, 10, 323-337. [CrossRef]

51. Miller, D.; le Breton-Miller, I. Managing for the Long Run: Lessons in Competitive Advantage from Great Family Businesses; Harvard Business Press: Brighton, UK, 2005.

52. Martínez, J.I.; Stöhr, B.S.; Quiroga, B.F. Family Ownership and Firm Performance: Evidence from Public Companies in Chile. Fam. Bus. Rev. 2007, 20, 83-94. [CrossRef]

53. Villalonga, B.; Amit, R. How do family ownership, control and management affect firm value? J. Financ. Econ. 2006, 80, 385-417. [CrossRef]

54. Mcconaughy, D.L.; Matthews, C.H.; Fialko, A.S. Founding Family Controlled Firms: Performance, Risk, and Value. J. Small Bus. Manag. 2001, 39, 31-49. [CrossRef]

55. Chrisman, J.J.; Chua, J.H.; Steier, L.P. The Influence of National Culture and Family Involvement on Entrepreneurial Perceptions and Performance at the State Level. Entrep. Theory Pr. 2002, 26, 113-130. [CrossRef]

56. Lee, J. Family Firm Performance: Further Evidence. Fam. Bus. Rev. 2006, 19, 103-114. [CrossRef]

57. A Zahra, S. International expansion of U.S. manufacturing family businesses: The effect of ownership and involvement. J. Bus. Ventur. 2003, 18, 495-512. [CrossRef]

58. Dyer, W.G.; Whetten, D.A. Family Firms and Social Responsibility: Preliminary Evidence from the S\&P 500. Entrep. Theory Pr. 2006, 30, 785-802. [CrossRef]

59. Post, J.E. The Greening of the Boston Park Plaza Hotel. Fam. Bus. Rev. 1993, 6, 131-148. [CrossRef]

60. Reiss, D. The Family's Construction of Reality; Harvard University Press: Cambridge, MA, USA, 1981; ISBN 0-674-29416-5.

61. Lee, P.M.; Pollock, T.G.; Jin, K. The contingent value of venture capitalist reputation. Strat. Organ. 2011, 9, 33-69. [CrossRef]

62. Pollock, T.G.; Lee, P.M.; Jin, K.; Lashley, K. (Un) Tangled Exploring the Asymmetric Coevolution of New Venture Capital Firms' Reputation and Status. Admin. Sci. Quart. 2015, 60, 482-517. [CrossRef]

63. Davis, J.H.; Schoorman, F.D.; Donaldson, L. Toward a stewardship theory of management. Acad. Manag. Rev. 1997, 22, 20-47. [CrossRef]

64. Eddleston, K.A.; Kellermanns, F.W. Destructive and productive family relationships: A stewardship theory perspective. J. Bus. Ventur. 2007, 22, 545-565. [CrossRef]

65. Bennedsen, M.; Foss, N. Family Assets and Liabilities in the Innovation Process. Calif. Manag. Rev. 2015, 58, 65-81. [CrossRef]

66. Bellow, A. In Praise of Nepotism: A History of Family Enterprise from King David to George W. Bush; Anchor: New York, NY, USA, 2004; ISBN 0-385-49389-4.

67. Jaskiewicz, P.; Uhlenbruck, K.; Balkin, D.B.; Reay, T. Is Nepotism Good or Bad? Types of Nepotism and Implications for Knowledge Management. Fam. Bus. Rev. 2013, 26, 121-139. [CrossRef]

68. Martin, G.; Gómez-Mejía, L.R.; Berrone, P.; Makri, M. Conflict between Controlling Family Owners and Minority Share-holders: Much Ado about Nothing? Entrep. Theory Pract. 2017, 41, 999-1027. [CrossRef]

69. De Angelo, H.; de Angelo, L. Controlling stockholders and the disciplinary role of corporate payout policy: A study of the Times Mirror Company. J. Financ. Econ. 2000, 56, 153-207. [CrossRef]

70. Schulze, W.S.; Lubatkin, M.H.; Dino, R.N.; Buchholtz, A.K. Agency Relationships in Family Firms: Theory and Evidence. Organ. Sci. 2001, 12, 99-116. [CrossRef]

71. Sharma, P.; Chrisman, J.J.; Chua, J.H. Strategic Management of the Family Business: Past Research and Future Challenges. Fam. Bus. Rev. 1997, 10, 1-35. [CrossRef]

72. Hall, A.; Melin, L.; Nordqvist, M. Entrepreneurship as Radical Change in the Family Business: Exploring the Role of Cultural Patterns. Fam. Bus. Rev. 2001, 14, 193-208. [CrossRef]

73. Morck, R.; Yeung, B. Agency Problems in Large Family Business Groups. Entrep. Theory Pr. 2003, 27, 367-382. [CrossRef]

74. Zahra, S.A.; Jennings, D.F.; Kuratko, D.F. The Antecedents and Consequences of Firm-Level Entrepreneurship: The State of the Field. Entrep. Theory Pr. 1999, 24, 45-65. [CrossRef]

75. Strang, G. Linear Algebra and Its Applications. Math. Comput. 1976, 30, 894. [CrossRef]

76. Geletkanycz, M.A.; Hambrick, D.C. The External Ties of Top Executives: Implications for Strategic Choice and Performance. Adm. Sci. Q. 1997, 42, 654. [CrossRef]

77. Gulati, R.; Higgins, M.C. Which ties matter when? the contingent effects of interorganizational partnerships on IPO success. Strat. Manag. J. 2002, 24, 127-144. [CrossRef] 
78. McDonald, M.L.; Westphal, J.D. Getting by with the Advice of Their Friends: CEOs' Advice Networks and Firms' Strategic Responses to Poor Performance. Adm. Sci. Q. 2003, 48, 1-32. [CrossRef]

79. Burt, R.S. Structural Holes and Good Ideas. Am. J. Sociol. 2004, 110, 349-399. [CrossRef]

80. Menon, T.; Pfeffer, J. Valuing Internal vs. External Knowledge: Explaining the Preference for Outsiders. Manag. Sci. 2003, 49, 497-513. [CrossRef]

81. Grossman, W. Intraindustry Executive Succession, Competitive Dynamics, and Firm Performance: Through the Knowledge Transfer Lens. J. Manag. Issues 2007, 340-361.

82. Wiersema, M.F. Strategic Consequences of Executive Succession within Diversified Firms. J. Manag. Stud. 1992, 29 , 73-94. [CrossRef]

83. Georgakakis, D.; Ruigrok, W. CEO Succession Origin and Firm Performance: A Multilevel Study. J. Manag. Stud. 2017, 54, 58-87. [CrossRef]

84. Zhang, Y.; Rajagopalan, N. When the Known Devil Is Better than an Unknown God: An Empirical Study of the Antecedents and Consequences of Relay CEO Successions. Acad. Manag. J. 2004, 47, 483-500. [CrossRef]

85. Bailey, E.E.; Helfat, C.E. External Management Succession, Human Capital, and Firm Performance: An Integrative Analysis. Manag. Decis. Econ. 2003, 24, 347-369. [CrossRef]

86. Fondas, N.; Wiersema, M. Changing of the Guard: The Influence of CEO Socialization on Strategic Change. J. Manag. Stud. 1997, 34, 561-584. [CrossRef]

87. Hill, C.W.; McShane, S.L. Principles of Management; McGraw-Hill/Irwin: Frankfurt, Germany, 2008.

88. March, J.G. Exploration and Exploitation in Organizational Learning. Organ. Sci. 1991, 2, 71-87. [CrossRef]

89. Bantel, K.A.; Jackson, S.E. Top management and innovations in banking: Does the composition of the top team make a difference? Strat. Manag. J. 1989, 10, 107-124. [CrossRef]

90. La Porta, R.; Lopez-De-Silanes, F.; Shleifer, A.; Vishny, R. Investor Protection and Corporate Valuation. J. Financ. 2002, 57, 1147-1170. [CrossRef]

91. Shleifer, A.; Vishny, R.W. A Survey of Corporate Governance. J. Financ. 1997, 52, 737-783. [CrossRef]

92. Demsetz, H.; Villalonga, B. Ownership structure and corporate performance. J. Corp. Financ. 2001, 7, 209-233. [CrossRef]

93. Beidleman, C.R. Income Smoothing: The Role of Management. Account. Rev. 1973, 48, 653-667.

94. Copeland, R.M. Income Smoothing. J. Account. Res. 1968, 6, 101. [CrossRef]

95. Trueman, B.; Titman, S. An Explanation for Accounting Income Smoothing. J. Account. Res. 1988, 26, 127. [CrossRef]

96. Bodie, Z.; Kane, A.; Marcus, A.J. Investments (The McGraw-Hill/Irwin Series in Finance, Insurance and Real Estate), 9th ed.; McGrawHill/Irwin: New York, NY, USA, 2011; ISBN 9780073530703.

97. Lins, K.V. Equity Ownership and Firm Value in Emerging Markets. J. Financ. Quant. Anal. 2003, 38, 159-184. [CrossRef]

98. Mitton, T. A cross-firm analysis of the impact of corporate governance on the East Asian financial crisis. J. Financ. Econ. 2002, 64, 215-241. [CrossRef]

99. Turner, A.L.; Weigel, E.J. Daily Stock Market Volatility: 1928-1989. Manag. Sci. 1992, 38, 1586-1609. [CrossRef]

100. Chatterjee, S.; Wernerfelt, B. The link between resources and type of diversification: Theory and evidence. Strat. Manag. J. 1991, 12, 33-48. [CrossRef]

101. Greve, H.R. Investment and the behavioral theory of the firm: Evidence from shipbuilding. Ind. Corp. Chang. 2003, 12, 1051-1076. [CrossRef]

102. Myers, S.C.; Majluf, N.S. Corporate financing and investment decisions when firms have information that investors do not have. J. Financ. Econ. 1984, 13, 187-221. [CrossRef]

103. Roodman, D. How to Do Xtabond2: An Introduction to Difference and System GMM in Stata. Stata J. 2009, 9, 86-136. [CrossRef]

104. Wooldridge, J.M. Econometric Analysis of Cross Section and Panel Data; MIT Press: Cambridge, UK, 2010.

105. Almeida, H.; Park, S.Y.; Subrahmanyam, M.G.; Wolfenzon, D. The structure and formation of business groups: Evidence from Korean chaebols. J. Financ. Econ. 2011, 99, 447-475. [CrossRef]

106. Greene, W.H. Econometric Analysis, 7th ed.; Prentice Hall: Boston, NJ, USA, 2012; ISBN 0-13-139538-6.

107. Ahn, S.C.; Schmidt, P. Efficient estimation of dynamic panel data models: Alternative assumptions and simplified estimation. J. Econ. 1997, 76, 309-321. [CrossRef]

108. Anderson, T.W.; Hsiao, C. Estimation of Dynamic Models with Error Components. J. Am. Stat. Assoc. 1981, 76, 598. [CrossRef]

109. Holtz-Eakin, D.; Newey, W.; Rosen, H.S. Estimating Vector Autoregressions with Panel Data. Econometric 1988, 56, 1371. [CrossRef]

110. Arellano, M.; Bover, O. Another look at the instrumental variable estimation of error-components models. J. Econ. 1995, 68, 29-51. [CrossRef]

111. Arellano, M. Panel Data Econometrics; Advanced Texts in Econometrics; Oxford University Press: Oxford, NY, USA, 2003; ISBN 0199245282.

112. StataCorp. Stata 15; StataCorp: College Station, TX, USA, 2017.

113. Cohen; West, S.G.; Aiken, L.S. Applied Multiple Regression/Correlation Analysis for the Behavioral Sciences; Routledge: Abingdon, UK, 2013.

114. Arellano, M.; Bond, S. Some Tests of Specification for Panel Data: Monte Carlo Evidence and an Application to Employment Equations. Rev. Econ. Stud. 1991, 58, 277. [CrossRef] 
115. Baltagi, B.H. Econometric Analysis of Panel Data, 4th ed.; John Wiley \& Sons: Chichester, UK; Hoboken, NJ, USA, 2008; ISBN 0470518863.

116. Besanko, D.; Dranove, D.; Shanley, M.; Schaefer, S. Economics of Strategy, 5th ed.; Wiley: Hoboken, NJ, USA, 2010; ISBN 047121213X.

117. Jensen, M.C. Agency Cost of Free Cash Flow, Corporate Finance, and Takeovers. SSRN Electron. J. 1999, 76, 323-329. [CrossRef]

118. Coase, R. The Nature of the Firm. Economica 1937, 4, 386-405. [CrossRef]

119. Morck, R.; Shleifer, A.; Vishny, R.W. Management ownership and market valuation. J. Financ. Econ. 1988, 20, 293-315. [CrossRef] 